motions and was soon rewarded by the passage of a large ascaris lumbricoides.

I am, Sirs, yours faithfully,

C. J. NEPEAN LONGRIDGE:

St. George's Hospital, S.W., June 21st.

\section{ENTERIC FEVER.}

\section{To the Editors of THE LANCET.}

ISrRs, -I have just read with much interest the Milroy Lectures, ${ }^{1}$ together with the discussion at the Epidemiological -Society on April 24th, 1900, and having had some experience of enteric fever I thought that you might allow me to make a few observations on its infectivity. In the year 1878 two sisters employed in the laundry of the Homerton Fever Hospital contracted enteric fever. Their special duty was to wash the "soiled" linen, a wurk in which they had been engaged for about two years without contracting any illness of any kind. They would in the performance of their duty have their hands very considerably soiled by the morbid miterial on the linen and if as has been long ago suggested, they had been in the habit of biting their nails or eating with unwashed hands they must have absorbed a not incon siderable quantity of it. Whether or not they did so may be open to a little doubt, but of the fact that during those two years they were free from any recognisable illness there is no doubt whatever.

On March 22nd, 1878, the brother of the younger sister's "young man" was admitted to the hospital with enteric fever, of which he became dangerously ill, and this younger sister more or less frequently risited him. On or about April 28th she began to be ill and on May 12th was sent to an enteric fever ward the subject of enteric fever. The elder sister visited the younger daily and on July 30 th was sent to an enteric fever ward the subject of enteric fever of about 10 days' duration.

He must be fort sur ses principes who can mistake the obvious meaning of facts like these, and they may be found in abundance in the papers of physicians from Piedvache (1850) to Goodall and others (1902).

I am, Sirs, yours faithfully,

June 22nd, 1902. ALEXANDER COLLIE.

\section{WHAT IS SCROFULA?}

To the Editors of THE LANCET.

SIRS, - The objections raised by your correspondent "Pes" in ThE LANCET of May 24th (p. 1498) and June 21st (p. 1799) in regard to the action of the Superintendent of Statistics in the General Register Office in retaining the term "scrofula" in his list of causes of death are, I venture to think, neither courteously set forth nor justifiable. It is surely unseemly to attack a public official of the acknowledged eminence of Dr. J. F. W. Tatham in such a manner and under the shelter of anonymity, and the case is not made better if it should happen that the assertions so confidently expressed are not proved to be in accordance with actual facts.

Your correspondent has evidently adopted the modern doctrine that all that was formerly regarded by the best clinical observers as indicative of a scrofulous or strumous habit of body is now, in the light of Koch's researches, to be considered as distinct proof or evidence of tuberculous invasion or influence. This view has, I regret to find, been rather widely adopted, especially by surgeons, but it cannot be regarded as adequate to meet the stern facts of clinical experience.

I discussed this question of the relation of tuberculosis to scrofula in an address delivered last October in Liverpool. This was published in THE LANCET of Nov. 9th, 1901, p. 1250, and again at greater length in the Iiverpool Medico-Chirurgical Journal for March, 1902. I maintained that the strumous habit of body should be regarded as presenting a peculiar condition of tissue proclivity, one sensitive and vulnerable to irritants of all kinds and specially prone to harbour and foster the bacillus of tubercle I maintained, further, that it was not inevitable for a scrofulous subject to become tuberculised and that such an individual might, and, indeed, often did. remain free from manifest tuberculosis throughout life. I quoted, and denied, Osler's statement to the effect that "scrofula is tubercle, as it has been shown that the

1 The LANCET, March 22nd (p. 793) and April 5th (p. 942), 12th (p. 1013), and 26th (p. 1155), and May 3rd (p. 1231), 1902. bacillus of Koch is the essential element," but stated my agreement with him when he went on to remark: "After all, as Virchow pointed out, an increased vulnerability of the tissue, however brought about, is the important factor in the disease."

We are not warranted in believing that all the ailments of the scrofulous subject are indicative of, and dependent upon, tuberculosis. No one, for example, would rightly regard the disorder known as ciliary blepharitis as a tuberculous condition, though instances of it are common enough in scrofulous children.

I am unable to follow your correspondent in his criticism of the terms "tubercular" and "tuberculous," but Dr. Tatham's use of the latter may safely be defended if et.ymology or morbid anatomy are in question.

I, therefore, entirely support the view taken by the authorities of the General Register Office, and am content, in the face of all that Koch has taught us, the value of which cannot be too highly appreciated, to hold with Watson, Paget, Simon, and many other clinical masters, that there is a condition of body to which the term "scrofula" is properly applicable. Inflammatory and other disorders are apt to assume a special type in scrofulous subjects, and this tendency modifies only too gravely many of these. Our duty to-day is to place Koch's discovery in its due relation to this diathetic strumous proclivity and not to displace all the older views in regard to this matter. Scrofula is not tuberculosis and tuberculosis is not scrofula and if anyone were absolutely to affirm the contrary I should venture to regard him as but slenderly equipped with true clinical instincts. The modern views in question are the progeny of the pathological laboratory. They neither emanate from, nor are they chastened by, the discipline of the bedside.

June 23rd, 1902. DYCE DUCKWORTH.

\section{THE SEED AND THE SOIL.}

To the Editors of THE LANCET.

SIRS,-The tenour of the admirable and statesman-like lectures recently delivered on "The Seed and the Soil" tend to make it appear that this question of "soil" is a new view in the elucidation of the causation of disease. But I would point out that this question of the necessity of suitability of soil was the constant contention of Lawson Tait more than a quarter of a century ago. In his persistent opposition to the teaching of Lister-that great man who has brought such honour to the House of Peers by his promotion to the peerage, who in future generations will take his rank in medicine with Hunter and Jenner, in religion with Luther, in teaching with Arnold, in science with Newton and Kelvin, in literature with Shakespeare, and in politics with Gladstone-his contention was that Lister's far-reaching researches, however true, only revealed half the truth. For he contested in no measured terms that it was immaterial how many millions of germs entered a wound provided no suitable soil were permitted for their germination.

When, if ever, the life and work of Lawson Tait comes to be written it will be manifest to generations to comewhen all his asperities, his failings, and his heinous faults are forgotten-that Lawson Tait's great work in the surgery of the abdomen holds the highest place in the annals of the surgery of the latter half of the nineteenth century. It was he who taught the profession the marvellous feats that could be performed in abdominal surgery and which have since borne fruit beyond his wildest expectations. His greatness will live when his littleness is forgotten. I am, Sirs, yours faithfully,

Rugby, June 26th, 1902.

ClEMENT DUKES.

\section{THE MEDICAL SERVICE OF THE MERCHANT MARINE.}

To the Editors of THE LA N $\mathrm{CET}$.

Sirs, - In ThE LANCET of June 28th, p. 1857, Dr. W. T. Burres of the R.M.S. Peru (or should it be Para?) complains bitteriy of the inadequate pay of ships' surgeons. I have been in the service of the very same company to which Dr. Burres belongs and consequently can speak with a certain amount of authority. Whilst in thorough accordance with your correspondent on the general principle that medical men should uphold the dignity of their profession by insisting upon proper remuneration 